\title{
Quality of milk produced by small and large dairy producers
}

\section{Qualidade do leite produzido por pequenos e grandes produtores}

\author{
Jose Carlos Ribeiro Junior ${ }^{*}$; Ronaldo Tamanini²; Livia Cavaletti Corrêa da Silva \\ Vanerli Beloti ${ }^{4}$
}

\begin{abstract}
The aim of this study was to compare the microbiological and physicochemical quality of raw milk produced by small and large dairy producers in Paraná, Brazil. Samples of raw milk were collected from small (49) and large (21) dairy producers. Dairy farms were characterized by observation and application of questionnaires. The total bacterial count (TBC) was obtained by flow cytometry and Petrifilm ${ }^{\circledR} \mathrm{AC}$, while the somatic cell count (SCC) was obtained by only flow cytometry. The content of fat, proteins, lactose, and solids in the mil were determined by infrared. Differences were observed in the techniques employed by small and large dairy producers, which may have influenced the microbiological quality of raw milk. Milk contamination significantly greater in milk produced by small farmers, which is evident from the average $\mathrm{TBC}$ of $3.8 \times 10^{6} \mathrm{CFU} / \mathrm{mL}$ obtained from milk produced by small farmers as compared to the TBC of $1.5 \times 10^{4} \mathrm{CFU} / \mathrm{mL}$ obtained from larger dairy farms. Twenty-four (49\%) small diary producers are no-compliant with the current standards for microbiological quality of refrigerated raw milk established by the law, while all larger producers were compliant with the standards. The average SCC of milk obtained from small producers was $2.2 \times 10^{5} \mathrm{SC} / \mathrm{mL}$, while that of large milk producers was $3.9 \times 10^{5} \mathrm{SC} / \mathrm{mL}$. Milk produced by small producers contained significantly higher fat, protein, lactose, and solids content. Milk produced by larger dairy farmers was mainly composed of lactose. In brief, the microbiological quality of milk from larger producers was higher, and SCC is proportional to the productivity. In addition, milk obtained from small dairy producers has a higher solid content.
\end{abstract}

Key words: Somatic cell count, total bacterial count, composition, fat, protein

\section{Resumo}

O objetivo do presente trabalho foi comparar a qualidade microbiológica e físico-química do leite cru refrigerado produzido por pequenos e grandes produtores do estado do Paraná, Brasil. Foram avaliadas amostras de leite cru refrigerado, oriundas de pequenos (49) e grandes (21) produtores. A caracterização das propriedades foi realizada através da observação e aplicação de questionários. A Contagem Bacteriana Total (CBT) foi realizada por citometria de fluxo e em Petrifilm ${ }^{\mathrm{TM}}$ AC, a Contagem de Células Somáticas (CCS) por citometria de fluxo e os percentuais de gordura, proteína, lactose e sólidos totais por infravermelho. Foram observadas diferenças de tecnificação entre os pequenos e grandes produtores, o que provavelmente influenciou a qualidade microbiológica do leite cru. A contaminação do leite foi substancialmente superior no leite produzido por pequenos produtores, como demonstrado pelas médias de CBT $3,8 \times 10^{6} \mathrm{UFC} / \mathrm{mL}$ e $1,5 \times 10^{4} \mathrm{UFC} / \mathrm{mL}$, respectivamente para pequenas e grandes propriedades.

\footnotetext{
${ }^{1}$ Discente de Doutorado do Programa de Pós-Graduação em Ciência Animal, Universidade Estadual de Londrina, UEL, Londrina, PR, Brasil. E-mail: jcribeiro.vet@hotmail.com

2 Dr. em Ciência Animal, Universidade Estadual de Londrina, UEL, Londrina, PR, Brasil. E-mail: ronaldot@gmail.com

${ }^{3} \mathrm{Dr}^{\mathrm{a}}$ em Ciência Animal, Laboratório Nacional Agropecuário Unidade Campinas, LANAGRO, Campinas, SP, Brasil. E-mail: liviacavaletti@gmail.com

${ }^{4}$ Prof $^{\mathrm{a}} \mathrm{Dr}^{\mathrm{a}}$, Dept ${ }^{\mathrm{o}}$ de Medicina Veterinária Preventiva, UEL, Londrina, PR, Brasil. E-mail: vbeloti@uel.br

* Author for correspondence
} 
Considerando o padrão vigente de qualidade microbiológica do leite cru refrigerado determinado pela legislação, 24 (49\%) pequenos produtores estão em desacordo, enquanto todos os grandes produtores estão em conformidade com a legislação. A CCS média foi de $2,2 \times 10^{5} \mathrm{CS} / \mathrm{mL}$ para os pequenos e 3,9 $\mathrm{x} 10^{5} \mathrm{CS} / \mathrm{mL}$ para os grandes produtores de leite. O leite oriundo dos pequenos produtores apresentou percentuais médios de gordura, proteína e sólidos totais significativamente superiores. O percentual de lactose foi o único quesito que apresentou resultado significativamente superior para o leite dos grandes produtores. Em suma, a qualidade microbiológica foi superior no leite de grandes produtores, os problemas com CCS são proporcionais à produtividade e a composição apresenta maior composição de sólidos no leite obtido por pequenos produtores.

Palavras-chave: Contagem de células somáticas, contagem bacteriana Total, composição, gordura, proteína

\section{Introduction}

There are several small dairy producers in the state of Paraná, in Brazil. These small milk producers are characterized by their minor production techniques and low zootechnical indices. They account for less than $23 \%$ of the national milk production, formally commercialized in Brazil with a productivity of up to 250 liters per day (IBGE, 2006). In the state of Paraná, however, the Castro region is famous for its milk production, where specialized properties have high milk production.

The microbiological quality of raw milk is still a serious problem in the milk production and dairy product industry. Several studies (BELOTI et al., 2011; FIALHO et al., 2012; RIBEIRO JÚNIOR et al., 2013) indicate that producers find it difficult to meet the goals for improvement of milk quality provided by Brazilian law (BRASIL, 2011).

The total bacterial count (TBC) of raw milk indicates the hygiene involved in obtaining, storing, and transportation of milk. Milk with a high bacterial count usually has problems such as acidity, which arises from microbial metabolism as a result of lactose degradation by saccharolytic bacteria (FRANCO; LANDGRAF, 2008) in addition to the degradation of lipids and proteins by lipolytic and proteolytic microorganisms, respectively, which decrease the life of the product.

The somatic cell count (SCC) of the milk, indicates the mammary gland health of the animals
(SANTOS; FONSECA, 2007). In the dairy industry, milk with high a SCC can alter the fermentation and coagulation of the technological processes aside from decreasing the production yields of dairy products, such as milk (CASTRO et al., 2014).

The aim of the present study is to determine the differences between $\mathrm{TBC}, \mathrm{SCC}$, and physicochemical components of raw milk produced by small and large producers of milk in the state of Paraná, Brazil.

\section{Materials and Methods}

Forty-nine milk samples collected between 2010 and 2014 from small producers in the municipalities of Sapopema, Faxinal, Jardim Alegre, and Ivaiporã, located in the northern-central region of the state of Paraná were analyzed. Small milk producers were characterized as those who delivered a daily average production of up to $1,000 \mathrm{~L}$ per day.

These samples were collected directly from the cooling tanks or cans at the time of milk collection for the dairy product. To perform TBC, $40 \mathrm{~mL}$ of milk was collected in sterile bottles containing azidiol and immediately refrigerated at the Laboratório da Rede Brasileira de Qualidade do Leite (RBQL) from the Associação Paranaense de Criadores de Bovinos da Raça Holandesa, located in Curitiba, Paraná. Simultaneously, another 40 $\mathrm{mL}$ of milk was collected in a sterile bottle with bronopol and transported to the same laboratory 
for physicochemical analysis to ascertain the fat, protein, lactose, and total solids content as well as the SCC.

The TBC and SCC were performed by flow cytomery (Bactocount - IBC and Somacount ${ }^{\circledR}-500$, Bentley Instruments, MN, USA, respectively), and the physicochemical composition was determined by infrared analysis (Bentley - 2000, Bentley Instruments, MN, USA).

Twenty-one samples of raw milk were collected directly from expansion tanks on the properties of large producers. One sample was collected in Londrina, 6 in Arapoti, and 14 in Castro, Paraná. Large producers were those who delivered a daily production of more than 5,000 L per day. From each property, $100 \mathrm{~mL}$ of milk was collected in sterile bottles and immediately refrigerated at the Laboratório de Inspeção de Produtos de Origem Animal (LIPOA) of the Universidade Estadual de Londrina (UEL). Proximate serial dilutions were made in saline $(0.85 \%)$, peptone $(0.1 \%)$, and seeded into Petrifilm ${ }^{\mathrm{TM}} \mathrm{AC}(3 M)^{5}$, followed by incubation at $37 \pm 1^{\circ} \mathrm{C}$ for $48 \mathrm{~h}$. The SCC and physicochemical composition of the milk from large producers were performed using the same methods as those employed for small producers and at the same laboratory.

All properties of the milk were characterized through observation and application of a questionnaire comprising of question of the milking type, hygiene during milking, milk storage method, daily volume of milk, number of animals and bovine breed on the property, and lactation.

For the statistical analyses of the data, SCC and TBC or aerobic mesophilic results were converted into $\log$ and the program Statistical ${ }^{\circledR}$ version 7.0 (StatSoft, OK, USA) was used for Student's t-test and formulation of graphics in the Box Plot.

\section{Results and Discussion}

The results of the questionnaires and observation showed that small producers used a milking bucked or milked with their foot or hand, used immersion tanks or community expansion, and the milk was not refrigerated. The average daily volume was $150 \mathrm{~L}$, and there were 52 animals on the property, 17 lactating. Crossbred animals were predominant. Good hygiene practices were not observed on any of the properties of small producers. Most of these producers also carry out other agricultural activities on their properties.

On the other hand, most of the large producers were exclusively dedicated to dairy cattle, with channeled mechanical and robotic milking, expansion tanks on the property, some with precooler plates, average daily production of 5,000 L, and 450 Hereford bovines or pure registered Jersey and 200 lactation animals. Good hygiene practices were observed during milking on all 21 properties.

Technological differences and good hygiene practices during the milking process of small and large producers directly influenced milk quality, especially the TBC and SCC, as observed in Table 1. Taffarel et al. (2013) proved that channelized mechanical milking, with bulk milk coolers provided better microbiological milk quality in comparison with mechanized milking with a bucket and use of foot or hands and cooling in immersion tanks.

The distribution of the results and means for TBC and SCC of milk obtained from small and large dairy producers are shown in Figure 1.

\footnotetext{
5 The differentiated methodology for microbiological count of the milk for large producers was due to the need to obtain isolated colonies for other studies. However, Jatobá (2009) found that the TBC methods by flow cytometry and Petrifilm ${ }^{\mathrm{TM}} \mathrm{AC}$ presented a coefficient of determination of 0.96 as compared to other methods.
} 
Table 1. Total Bacterial Count (TBC) and somatic cell count (SCC) of refrigerated raw milk produced by small and large producers in Paraná, Brazil during 2010-2014.

\begin{tabular}{cccccc}
\hline \multirow{2}{*}{ Interval $(\times \mathbf{1 0} / \boldsymbol{m L})$} & \multicolumn{3}{c}{ Small } & \multicolumn{3}{c}{ Large } \\
\cline { 2 - 5 } & $1-100$ & 13 & 26.53 & $\boldsymbol{n}$ & $\boldsymbol{\%}$ \\
\hline \multirow{3}{*}{ TBC } & $100-200$ & 4 & 8.16 & 1 & 95.24 \\
& $200-400$ & 3 & 6.12 & 0 & 4.76 \\
& $400-600$ & 5 & 10.20 & 0 & 0 \\
& $600-800$ & 1 & 2.05 & 0 & 0 \\
& $800-1000$ & 4 & 8.16 & 0 & 0 \\
& $>1,000$ & 19 & 38.78 & 0 & 0 \\
& & & & 0 \\
& $1-100$ & 18 & 36.74 & 0 & 23.80 \\
& $100-200$ & 13 & 26.54 & 5 & 52.38 \\
& $200-400$ & 11 & 22.44 & 11 & 4.76 \\
$400-600$ & 1 & 2.04 & 1 & 9.52 \\
& $600-800$ & 3 & 6.12 & 2 & 0 \\
& $800-1,000$ & 2 & 4.08 & 0 & 9.52 \\
\hline
\end{tabular}

Figure 1. Distribution and mean total bacterial count (TBC) and somatic cell count (SCC) of refrigerated raw milk of 49 small and 21 large producers in Paraná, Brazil between 2010 and 2013, except the extremes and outliers.

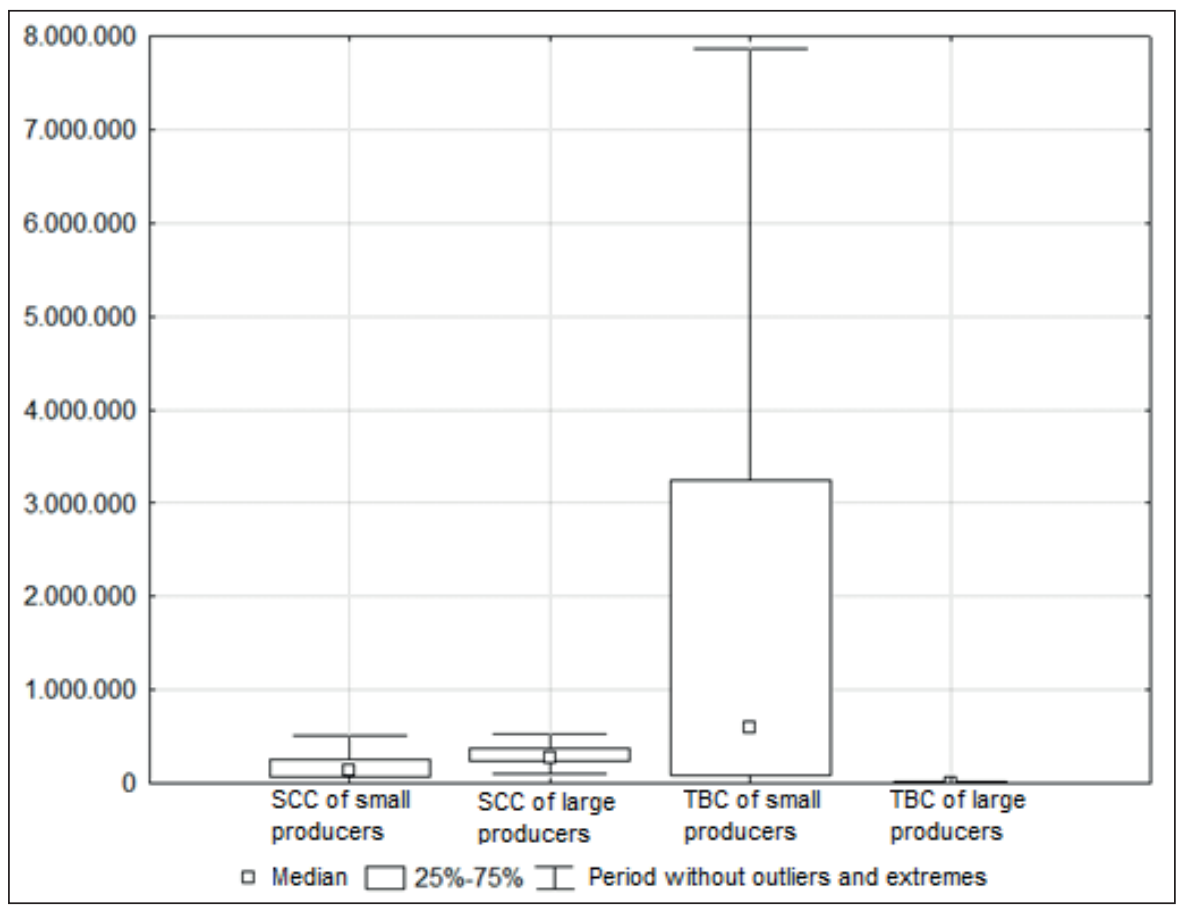

The TBC in milk from small producers is presented bacterial counts lower than $1 \times 10^{5} \mathrm{CFU} /$ statistically higher than that of large producers, as $\mathrm{mL}$ and none presented counts higher than $2 \times 10^{5}$ shown in Table 2. While $95 \%$ of large producers CFU/mL, $60 \%$ of small producers were found to have 
counts higher than $4 \times 10^{5} \mathrm{CFU} / \mathrm{mL}$. This is mainly due to the hygiene practices followed by large producers, aside from the fast cooling of the milk, which reduces the multiplication of mesophilic microflora in large properties. Furthermore, large producers are involved in programs that pay according to milk quality, which encourages them to obtain low counts. Small producers do not receive financial encouragement to maintain low levels of bacterial counts, which discourages their efforts to improve their milk quality.

Table 2. Average values of total bacterial count (TBC), somatic cell count (SCC), and physicochemical constituents of refrigerated raw milk produced by small and large producer in Paraná, Brazil during 2010-2014.

\begin{tabular}{cccccc}
\hline & \multicolumn{2}{c}{ Small producers } & \multicolumn{2}{c}{ Large producers } & \multirow{2}{*}{ p-value } \\
\cline { 2 - 5 } & Average* & Standard Deviation & Average* & Standard Deviation & \\
\hline TBC $(\mathbf{C F U} / \mathbf{m L})$ & $3.8 \times 10^{6 \mathrm{a}}$ & $\pm 7.2 \times 10^{6}$ & $1.5 \times 10^{4 \mathrm{~b}}$ & $3.4 \times 10^{4}$ & $3.1 \times 10^{-4}$ \\
SCC (CS/mL) & $2.2 \times 10^{5 \mathrm{a}}$ & $\pm 2.5 \times 10^{5}$ & $3.9 \times 10^{5 \mathrm{~b}}$ & $3.3 \times 10^{5}$ & $1.7 \times 10^{-2}$ \\
Fat (\%) & $4.08^{\mathrm{a}}$ & \pm 1.02 & $3.47^{\mathrm{b}}$ & 0.50 & $1.2 \times 10^{-4}$ \\
Protein (\%) & $3.60^{\mathrm{a}}$ & \pm 0.58 & $3.16^{\mathrm{b}}$ & 0.19 & $8.0 \times 10^{-6}$ \\
Lactose (\%) & $4.46^{\mathrm{a}}$ & \pm 0.28 & $4.54^{\mathrm{b}}$ & 0.13 & $4.7 \times 10^{-2}$ \\
Total Solids (\%) & $13.07^{\mathrm{a}}$ & \pm 1.30 & $12.16^{\mathrm{b}}$ & 0.64 & $1.2 \times 10^{-4}$ \\
\hline
\end{tabular}

*Values followed by different letters in the same line differ from each other in Student's t-test at 5\% level of probability.

Considering the current standard of microbiological quality of refrigerated raw milk as determined by Brazilian law (BRASIL, 2011) of 6 $\times 10^{5} \mathrm{CFU} / \mathrm{mL}, 24(49 \%)$ small producers present counts higher than the standard, while 21 (100\%) large producers conform with the standards set. The same law determines the reduction of count to $1 \times 10^{5} \mathrm{CFU} / \mathrm{mL}$, with effect from July 2016 . Considering the new standards for TBC, $73.46 \%$ of small and $4.74 \%$ of large producers would have to implement or improve their hygiene practices during milking to reduce the TBC.

For SCC, it was found that large producers presented counts significantly higher than small producers (Table 2). It is known that mastitis frequently affects animals with higher fitness, higher degree of purity, and higher milk production (RIBEIRO JÚNIOR et al., 2013). Since small diary usually own mixed breeds and low milk producing animals, it was expected that the SCC would be lower for these producers.

Therefore, the main problem with milk quality from large producers is the SCC, since bacterial contamination is controlled, in contrast to small producers, where the bacterial counts are the main problem.

For SCC, the current standard according to the Normative Instruction no. 62 (BRASIL, 2011) is 6 $\times 10^{5} \mathrm{SC} / \mathrm{mL}$ with a reduction to $4 \times 10^{5} \mathrm{CS} / \mathrm{mL}$, with effect from July 2016. Considering the current standard, 6 (12.24\%) small and 4 (19.07\%) large producers analyzed in the present study were not in conformance with the current standards. Making a prospection for the 2016 SCC standard, 7 (14.28\%) small and $5(23.80 \%)$ larger producers would have higher counts.

The answer to lowering the SCC is implementation of good hygienic practices in the milking process and this is not an immediate solution as it is for TBC, which can have a count reduction from $96 \%$ on the first day of execution (MATSUBARA et al., 2011). To reduce somatic cells, it is recommended that producers deploy other practices such as identification and treatment of clinical and subclinical mastitis, appropriate handling of animals with subclinical mastitis, 
leaving them after milking, discarding animals with recurring mastitis, and applying prophylactic intramammary antibiotics at the end of lactation (SANTOS; FONSECA, 2007).

The percentages of fat, protein, total solids was also higher in milk obtained from small producers in comparison to that from large producers, which was also expected, since higher production animals, especially Herefords, tend to present milk with lower concentrations of fat and protein (SANTOS; FONSECA, 2007). Thereby, productivity differences also lead to a higher concentration of protein and fat in the milk of the animal that produces less milk.

As the lactose percentage is related to the quantity of milk produced, by influencing the quantity of water in the milk (SANTOS; FONSECA, 2007), small milk producers can present lower percentages in comparison with large producers, who produce more milk, but with a more diluted constituent.

Large dairy producers generate milk with a better microbiological quality than small producers. However, this milk has a higher SCC and lower concentrations of fat and protein. These differences are related to the technology used on the properties, hygienic practices employed, and the fitness and diet of the animal.

\section{References}

BELOTI, V.; RIBEIRO JÚNIOR, J. C.; TAMANINI, R.; YAMADA, A. K.; SILVA, L. C. C. da; SHECAIRA, C. L.; NOVAES, D. G.; SILVA, F. F.; GIOMBELLI, C. J.; DIEKMAN, F.; SILVA, M. R. Qualidade microbiológica e físico-química do leite cru refrigerado produzido no município de Sapopema/PR, Revista Científica Eletrônica de Medicina Veterinária, Garça, v. 9, n. 16, p. 2-9, 2011. Disponível em: <http://faef. revista.inf.br/imagens_arquivos/arquivos_destaque/ gvRfHOQjI5PmOHd_2013-6-25-16-55-49.pdf $>$. Acesso em: 7 jul. 2014.

BRASIL. Ministério da Agricultura, Pecuária e Abastecimento. Instrução Normativa $\mathrm{n}^{\circ} 62$, de 29 de dezembro de 2011. Diário Oficial [da] República Federativa do Brasil, Brasília, 31 dez. 2011, Seção 1, p. 6.

CASTRO, K. A.; SILVA, K. A. L.; PEREIRA, A. I.
A.; ORSINE, J. V. C. Efeito da contagem de células somáticas sobre a qualidade dos queijos prato e mussarela. Revista Brasileira de Tecnologia Agroindustrial, Ponta Grossa, v. 8, n. 1, p. 1237-1250, 2014. Disponível em: $<$ http://revistas.utfpr.edu.br/pg/index.php/rbta/article/ view/1484>. Acesso em: 7 de jul. 2014.

FIALHO, T. L.; EUGÊNIO, M. H. A.; SILVÉRIO, A. S. D.; MELO, C. M. S.; ABREU, L. R.; PINTO, S. M. Evolução da qualidade do leite de cooperativas da região do Alto Paranaíba perante a instrução normativa 51. Revista do Instituto de Laticínios Candido Tostes, Juiz de Fora, v. 67, n. 385, p. 53-57, 2012. Disponível em: $<$ http:// www.revistadoilct.com.br/rilct/article/view/213>. Acesso em: 7 jul. 2014.

FRANCO, B. D. G. M.; LANDGRAF, M. Microbiologia dos alimentos. 2. ed. São Paulo: Atheneu, 2008. 182 p.

INSTITUTO BRASILEIRO DE GEOGRAFIA E ESTATÍSTICA - IBGE. SIDRA - Censo agropecuário de 2006. Disponível em: <http://www.sidra.ibge.gov.br>. Acesso em: 30 jun. 2014.

JATOBÁ, R. B. Estabelecimento de uma curva de calibração para o equipamento Bactocount para o monitoramento da qualidade do leite. 2009. Dissertação (Mestrado em Zootecnia) - Universidade Federal de Pernambuco, Recife.

MATSUBARA, M. T.; BELOTI, V.; TAMANINI, R.; FAGNANI, R.; SILVA, L. C. C.; MONEIRO, A. A.; BATAGLINNI, A. P. P.; ORTOLANI, M. B. T.; BARROS, M. A. F. Boas práticas de ordenha para redução da contaminação microbiológica do leite no agreste Pernambucano. Semina: Ciências Agrárias, Londrina, v. 31, n. 1, p. 277-286, 2011. Disponível em: $<$ http://www.uel.br/revistas/uel/index.php/semagrarias/ article/view/3283>. Acesso em: 7 jul. 2014.

RIBEIRO JÚNIOR, J. C.; BELOTI, V.; SILVA, L. C. C.; TAMANINI, R. Avaliação da qualidade microbiológica e físico-química do leite cru refrigerado produzido na região de Ivaiporã, Paraná. Revista do Instituto de Laticínios Candido Tostes, Juiz de Fora, v. 68, n. 392, p. 5-11, 2013. Disponível em: http://www.revistadoilct. com.br/rilct/article/view/23/27>. Acesso em: 7 jul. 2014.

SANTOS, M. V.; FONSECA, L. F. L. Estratégias para controle de mastite e qualidade do leite. São Paulo: Lemos Editorial, 2007. 314 p.

TAFFAREL, L. E.; COSTA, P. B.; OLIVEIRA, N. T. E.; BRAGA, G. C.; ZONIN, W. J. Contagem bacteriana total do leite em diferentes sistemas de ordenha e de resfriamento. Arquivos do Instituto Biológico, São Paulo, v. 80 , n. 1, p. 7-11, 2013. Disponível em: <http://www. scielo.br/pdf/aib/v80n1/a02v80n1.pdf $>$. Acesso em: 7 jul. 2014. 